Dissertations-Abstract

\title{
An autochthonous mouse model of MYD88 p.L265P- and BCL2-driven diffuse large B cell lymphoma
}

Autor: Gero Knittel

Prüfungsdatum: 11.01.2019

Erstprüfer: Prof. Dr. Björn Schumacher

Zweitprüfer: Prof. Dr. Manolis Pasparakis

Schlagwörter: Lymphom, Diffus-großzelliges B-Zell Lymphom, Mausmodell, MYD88, DLBCL

Keywords: Lymphoma, diffuse large B cell lymphoma, mouse model, MYD88, DLBCL

Zusammenfassung deutsch:

Das Adapterprotein MYD88 spielt eine essentielle Rolle bei der Aktivierung von NFKB durch den Toll-like-Rezeptor Signalweg. Mutationen in MYD88, insbesondere die Punktmutation p.L265P, wurden in verschiedenen B-Zell-Tumoren gefunden, unter anderem im diffus-großzelligen B-Zell-Lymphom (engl. diffuse large B cell lymphoma, DLBCL). Etwa 18\% aller DLBCL-Fälle sind MYD88-mutiert, wobei diese Mutationen stark im sogenannten "Activated B cell-like" (ABC) Subtypus von DLBCL angereichert sind. Der Großteil dieser Mutationen in MYD88 resultieren in der Variante p.L265P, für welche gezeigt wurde, dass sie zu Stimulus-unabhängiger NFkB-Aktivierung führt.

Das Ziel dieser Thesis war, die Rolle der MYD88 p.L265P Mutation in der Lymphomagenese zu untersuchen. Es wurde ein Mausmodell genereriert, welches die Cre- vermittelte konditionale Expression von Myd88 p.L252P (dem murinen Ortholog der humanen MYD88 p.L265P-Variante) vom endogenen Lokus erlaubt.

Da die Überexpression von BCL2 eine häufiges Merkmal von ABC DLBCL ist, wurde dieses Myd88-Allel (abgekürzt "M") mit einem BCL2-Überexpressionsallel (abgekürzt "B") kombiniert. Beide Allele wurden dann durch B Zell-spezifische Expression von Cre (durch Verwendung des CD19:Cre-Allels, abgekürzt "C") aktiviert. Die generierten MBC-Mäuse zeigen eine gesteigerte Aktivität des B Zell-Kompartiments, angezeigt durch eine erhöhte Anzahl aktiver Keimzentren, Keimzentrums-erfahrener B ZellSpezies und Immunglobulinen im Serum. Diese Überaktivierung ist zumindest teilweise auf den Verlust der Selbsttoleranz zurückzuführen, da MBC-Tiere erhöhte Konzentrationen selbstreaktiver Antikörper aufweisen. In MC- und BC-Tieren wurden ebenfalls vermehrt autoreaktive Immunglobuline gefunden, wenngleich in einem geringeren Ausmaß.

Immunisierungsexperimente zeigten, dass während Myd88 p.L252P primär die Antwort auf thymusunabhängige Antigene vestärkt, BCL2 Überexpression größere Effekte in der Immunantwort auf thymusabhängige Antigene zeigt. Beide Mutationen kooperieren bei der Generierung der stärksten humoralen Antworten in MBC-Tieren. Schlussendlich entwickeln MBC-Tiere Tumore, primär im Mesenterium. Diese Läsionen sind klonal und entprechen morphologisch DLBCL mit großen, blastären Zellen mit dem Immunophänotyp einer keimzentrumserfahrenen Zelle (BCL6-/ IRF4+/ B220-/ CD138+). Transkriptionsprofile der Tumore zeigten eine signifikante Anreicherung ABC DLBCL-assoziierter Genexpressionssignaturen im Vergleich zu

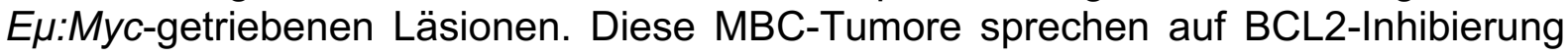
durch den Wirkstoff ABT-199 in vitro und in vivo an. Hemmung von IRAK4 durch zwei unterschiedliche pharmakologische Substanzen zeigte mäßige Effekte in vitro, die aber nicht in einem Überlebensvorteil in vivo resultierten. Außerdem zeigen MBC- 
Tumore eine höhere Expression von PD-L1 als E $\mu$ :Myc-Tuomre, und Behandlung mit einem $\alpha$-PD-1-Antikörper hatte wachstumsstabilisierende Effekte auf den Tumor.

Zusammengefasst wurde ein neues, von Myd88 p.L252P und BCL2-Überexpression getriebenes, Mausmodell für ABC DLBCL generiert. Der Tumorbildung geht ein hyperaktiver Zustand de B Zell-Kompartiments voran, charakterisiert durch gesteigerte humorale Antworten auf exogenes Antigen sowie den Verlust von Selbsttoleranz. MBC-Tumore sprechen auf die Inhibierung von BCL2 sowie der PD-L1/PD-1Interaktion an, was eine mögliche Anwendbarkeit dieser Behandlungen in der Therapie von $A B C$ DLBCL suggeriert.

\section{Abstract english:}

The adaptor protein MYD88 is critical to relay activation of Toll-like receptor signaling to NFKB activation. MYD88 mutations have been described in different $\mathrm{B}$ cell malignancies, including diffuse large B cell lymphoma (DLBCL). Around $18 \%$ of DLBCL cases are mutated in MYD88, and these cases are strongly enriched in the activated $B$ cell-like $(A B C)$ subtype of DLBCL. The majority of these mutations represent the p.L265P point mutation, which has been shown to cause stimulus-independent signaling, resulting in NFKB activation.

The aim of this study was to investigate the role of the p.L265P mutation in lymphomagenesis. A mouse model was generated, where Cre-mediated recombination leads to the conditional expression of Myd88 p.L252P (the orthologous position of the human MYD88 p.L265P mutation) from the endogenous locus.

This Myd88 allele (abbr. M) was combined with a BCL2 overexpression allele (abbr. $B$ ), as BCL2 overexpression is a common feature of ABC DLBCL, and both alleles were activated B cell-specifically with CD19:Cre (abbr. C). These MBC mice show a hyperreactive $B$ cell compartment, indicated by increased numbers of germinal centers, post-germinal center B cell species and serum immunoglobulins. This hyperactivation is, at least in part, the result of a loss of self-tolerance, as MBC animals show elevated levels of self-reactive antibodies. Elevated levels of autoreactive immunoglobulins were also found in $\mathrm{MC}$ and $\mathrm{BC}$ animals, albeit to a lower extent.

Immunization experiments revealed that whereas Myd88 p.L252P greatly enhances the response to thymus-independent antigen, the effects of $B C L 2$ overexpression are stronger in response to thymus-dependent antigen, and both mutations cooperate in generating the strongest responses in MBC animals.

Ultimately, MBC animals develop tumors, mainly in the mesenterial area. These lesions were shown to be clonal, and they morphologically resemble DLBCL. The infiltrates consisted of large blastoid cells with a post-germinal center immunophenotype (BCL6-/ IRF4+/ B220-/ CD138+). Compared to EM:Myc-driven lesions, the tumor transcription profiles were enriched for $A B C$ DLBCL gene expression signatures. These MBC tumors were exquisitely sensitive to inhibition of BCL2 by ABT-199 in vitro and in vivo. Inhibition of IRAK4 by two experimental compounds showed some effect on cell viability in vitro, which did not translate into a survival benefit in vivo. MBC tumors expressed PD-L1 at elevated levels, compared to $E \mu: M y c$ tumors and treatment with an a-PD1 antibody had stabilizing effects on tumor growth.

Taken together, a novel mouse model for ABC DLBCL-like disease, driven by Myd88 p.L252P and BCL2 overexpression, was established. Tumor formation is preceded by a hyperactivated state characterized by exaggerated responses to exogenous antigen and the break of self tolerance. MBC tumors are sensitive to the inhibition of BCL2 by ABT-199 and respond to immune checkpoint blockade by a-PD1 treatment, suggesting these treatments as potential new strategies in the therapy of ABC DLBCL. 